\title{
THE EFFECTS OF LIFE CYCLE AND FREE CASH FLOW ON DIVIDEND OF AGRICULTURAL COMPANIES THAT LISTED IN INDONESIA STOCK EXCHANGE
}

\author{
Helma Malini $^{* 1}$, Venu Fitratama ${ }^{1}$ \\ ${ }^{1}$ Management Department Faculty of Economics and Business, Tanjungpura University \\ e-mail: ${ }^{* 1}$ helma.malini@ekonomi.untan.ac.id
}

\begin{abstract}
Company decision to give profits to their investors is based on several reasons including internal policy from the company. Therefore, this study discusses the effects of life cycle and free cash flow on dividend of agricultural companies that listed in Indonesia stock exchange. Independent variables; used are free cash flow, life cycle, firm size, leverage, assets growth, and investment opportunity set. The population in this study is Agricultural company listed on Indonesia Stock Exchange (BEI) in the period of 2015 - 2018. The sample collected using purposive sampling methods. Total of 21 companies were determined as samples. The method of analysis in this study is panel data regression with basis on fixed effect model. The result of this study indicate that the independent variables of free cashflow, life cycle, firm size, leverage, and investment opportunity set have positive impact toward dividend payout ratio while assets growth has negative impact on dividend payout ratio. The result of determination coefficient shows that the independent variables give affect $63.69 \%$ against dependent variable.
\end{abstract}

Keywords: free cash flow, life cycle, firm size, leverage, assets growth, investment opportunity set, dividend payout ratio, dividend policy.

\section{INTRODUCTION}

Clientele effect theory explained that investors, who have a greater preference for dividends, see dividends as more certain than capital gains (Keown, Martin, Petty, \& Scott,2003). Investors who prefer dividends expect that the level of dividend distribution and growth will be adjusted to the profits of the company. The relationship between stock prices and dividend policy is supported by the Bird in the Hand theory expressed by Gordon (1963) and Lintner (1962). According to the theory, dividend policy has a positive effect on companies stock price. However, this theory is refuted by the Dividend Irrelevant theory expressed by Miller and Modigliani (1961) which stated that stock price is influence by profit-making activities rather than dividen policy.

In the implementation, Black (1976) stated that dividend policy is like a puzzle, therefore dividend policy are significant in financial sector. Various studies on dividend behaviour have been conducted found an acceptable explanation on the imprtance of dividend policy (Black, 1976; Allen \& Michaely, 2003). Dividend policy is made by managers by considering the determination of how much profit is distributed as dividends and how much portion is retained earnings (Levy and Sarnat, 1990; in Rosdini, 2009). Dividend distribution is largely influenced by the behaviour of investors who prefer high dividends, because dividends that distribute today are more valuable than the capital gains obtained later. On the contrary, 
management needs to hold cash to pay off debt or increasing investment in form of expansion (Suharli \& Rachpriliani, 2006).

On the other hand, management needs to implement optimal dividend policies to create a balance between current dividends and future growth (Brennan \& Thakor, 1990) where it become the mechanism for controlling shareholders of the management (Suharli \& Rachpriliani, 2006). Cash dividend policy according to (Kallapur \&Trombley, 1999) demonstrated through dividend payout ratios and dividend yields. Payment of dividends, especially cash dividends to shareholders, is highly dependent on the cash position available. This is proven by research conducted by Sutrisno (2001) in Rosdini (2009) which stated that among several factors that influence the Dividend Payout Ratio, only cash position factor and Debt to Equity Ratio have a significant effect. Cash positions that are truly available to shareholders will be reflected in the free cash flow owned by the company.

Jensen (1986) defines free cash flow as cash remaining after all projects that generate positive net present value. Walsh (2003) in Gustiana (2009) defines free cash flow as discretionary cash flow available to companies. Free cash flow is cash from operating activities minus capital expenditures company spends to meet current production capacity. Free cash flow have a purpose for discretionary uses such as acquisition and capital expenditure with growth orientation, debt repayment, and payment to shareholders in the form of dividends. Companies with excess free cash flow will have better performance than other companies because they have cash available for growth, debt payments and dividends. They can benefit from various opportunities that other companies might not.

The expected results of this study is to investigate whether the availability of free cash flow of agricultural company influence cash dividend payment policies to shareholders. Since, agricultural company are seasonality, perishability, and variability thus making their free cash flow depends on their characteristics.

\section{RESEARCH METHOD}

\section{Conceptual Framework}

This study use six independent variables and one dependent variable. Independent variable consist of Free Cash Flow (X1), Life Cycle(X2), Firm Size (X3), Leverage (X4), Assets Growth (X5) and Investment Opportunity Set (X6). Dependent variable in this research is Dividend Payout Ratio (Y). Based on the background, formulation of problem, research purposes and previous research, the research model is as follow :

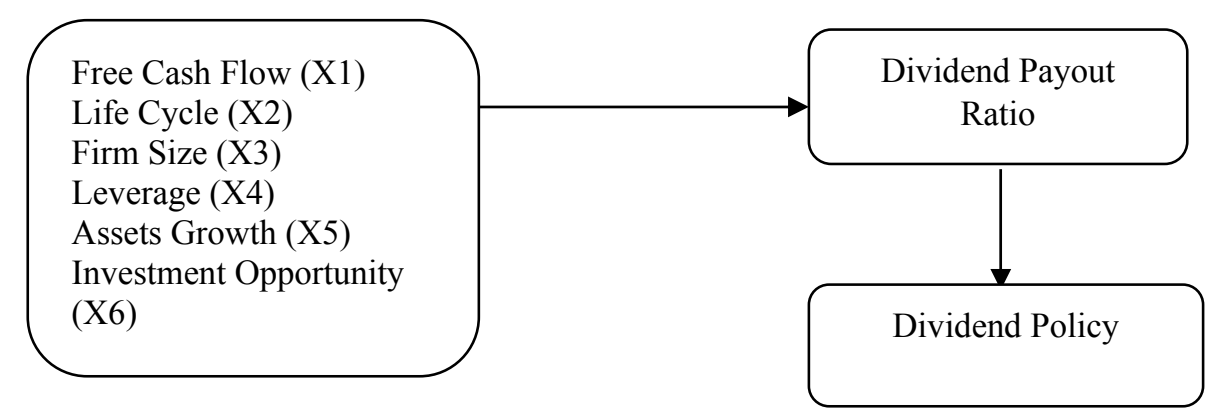

Figure 1. Conceptual Framework 


\section{Research Hypothesis}

H1: Free cash flow positively affects dividend payout ratio.

H2: Company's life cycle positively affect dividend payout ratio.

H3: Firm size positively affect dividend payout ratio

H4: Leverage negatively affect dividend payout ratio

X5: Assets growth negatively affect dividend payout ratio

X6: Investment opportunity set positively affect dividend payout ratio

\section{Data}

Data obtained indirectly from third parties ; Indonesian stock exchange website, yahoo finance, BPS, Investing anf Wall Street Journal's. The data collection method used by researchers is the documentation method which is collecting data from audited financial statements of agricultural companies that listed in Indonesia Stock Exchange from 2015 to 2018 .

\section{Population and Sample}

The population in this study is agricultural companies listed on the Indonesia Stock Exchange (IDX) from 2015 to 2018. Sample criteria to be examined include the following:

1. Agricultural companies listed in Indonesia Stock Exchange and publish their financial reports.

2. Agricultural companies that have variables related to research measured by Free Cash Flow, Life Cycle, Firm's Size, Leverage, Asset Growth and Investment Opportunity set.

3. Agricultural companies that publish financial reports from 2015 to 2018 in succession.

4. Agricultural companies that distribute dividends in 2015 to 2018 continuously.

\section{Method of Analysis}

1. Descriptive Statistics

The descriptive statistics are used to explain the mean, standard deviation, average, and minimum data values. This analysis allows the writer to view the raw data in a meaningful way by summing the data. Hence, the writer will define the uncertainty and error in the data as well as minimize the occurrence of the question of sample distribution.

2. Model Specifications

Random effect and fixed effect model validation were also employed to further verify the findings. The econometric model under analysis is:

$$
Y_{i t}=C_{i t}+\beta_{1 .} X_{1 i t}+\beta_{2 .} X_{2 i t}+\beta_{3 .} X_{3 i t}+\beta_{4 .} X_{4 i t}+\mathcal{E}_{i t}
$$

Whereas:

$$
\begin{array}{ll}
\boldsymbol{Y} & =\text { Dividend Payout Ratio } \\
\boldsymbol{X}_{\boldsymbol{1}} & =\text { Free Cash Flow } \\
\boldsymbol{X}_{2} & =\text { Company's Life Cycle } \\
\boldsymbol{X}_{3} & =\text { Firm's Size } \\
\boldsymbol{X}_{4} & =\text { Leverage } \\
\boldsymbol{i} & =\text { each firm } \\
\boldsymbol{t} & =\text { each period (year) }
\end{array}
$$




\section{a. Common Effect Model}

This method is the simplest of all panel data regression models, since it incorporates both cross section and time series data as a whole, without supervising the time and cross differences. The Ordinary Least Square (OLS) is the most common approach utilized in this model.

\section{b. Fixed Effect Model}

The Fixed Effect Model method uses an assumption that all intercepts are different from each cross section, while the slopes remain constant. In order to differentiate each cross data this technique uses dummy variable, so the intercept will also be different.

\section{c. Random Effect Model}

Random Effect Model assumes intercepts are different for each cross data, assuming the intercepts are random (stochastic) variables. The model will mostly be helpful if the sample was taken randomly to represent the research data against the population. This technique also assumes that the errors between the cross section and time series could be correlated.

3. Chow Test (F-statistics)

This test will assess if Fixed Effect is more suitable than Popular Effect. The outcome of this test could be interpreted with respect to the value of the F-probability. Therefore, we cannot dismiss null hypothesis if the significance is more than 5 per cent. If the value is less than $5 \%$, thus we should reject the null hypothesis. The null hypothesis will consider the Standard Effect, while the Fixed Effect will accept the alternative hypothesis.

4. Hausman Test

Hausman created a method for determining whether Fixed Effect is more acceptable than Random Effect. The concept was based on Least Squares Dummy Variables (LSDV) on Fixed Effect will be more effective on Random Effect System rather than Generalized Least Squares (GLS). The null hypothesis thus supports the Random Effect, while the alternative hypothesis refuses the Random Effect.

\section{RESULT AND DISCUSSION}

\section{Descriptive Statistics Analysis}

Table 1. Descriptive Statistics

\begin{tabular}{lccccccc}
\hline \multicolumn{1}{c}{ Item } & $\mathbf{Y}$ & $\mathbf{X 1}$ & $\mathbf{X 2}$ & $\mathbf{X 3}$ & $\mathbf{X 4}$ & $\mathbf{X 5}$ & $\mathbf{X 6}$ \\
\hline Mean & 8.170206 & 0.108694 & 0.408830 & 155.9196 & 8.037809 & 6.795278 & 28.20391 \\
Median & 8.258682 & 0.083078 & 0.399475 & 150.2080 & 8.121480 & 6.782192 & 15.87897 \\
Maximum & 11.20482 & 0.411153 & 0.824523 & 196.5820 & 9.011524 & 8.983063 & 425.1109 \\
Minimum & 5.587249 & -0.111843 & -0.428340 & 122.0040 & 6.645091 & 4.189655 & - \\
& & & & & & & 1.758 .262 \\
Std. Dev. & 0.941491 & 0.105345 & 0.214260 & 17.79342 & 0.535969 & 0.929144 & 50.99985 \\
Skewness & -0.247253 & 1.137960 & -0.532395 & 0.363321 & -0.398995 & -0.084940 & 5.912699 \\
Observations & 97 & 97 & 97 & 97 & 97 & 97 & 97 \\
\hline
\end{tabular}

Source: Eviews 9.0 (Processed Data) 
Based on table 3.1, number of total observations are 97, with 28 cross section data and 4-year period. The dependent variable $\mathrm{Y}$ represents the dividend payout ratio, which has minimum value by 5.587249 and the maximum value by 11.20482 . It means the standard deviation of the agricultural companies' dividend payout ratio has minimum value by 5.587249 point, and maximum value by 11.20482 point. The average of the dividend payout ratio is 8.170206 which considered quite volatile. Moving on the skewness and kurtosis of the dividend payout ratio, it shows that the overall volatility of the sample is normally distributed, which means the level of the volatility is quite similar for all cross section.

Table 2. Common Effect Model Result

\begin{tabular}{ccccc}
\hline Variable & Coefficient & Std. Error & t-Statistic & Prob. \\
\hline C & 8.013375 & 1.512326 & 5.298709 & 0.0000 \\
X1 & 2.858055 & 0.869198 & 3.288151 & 0.0014 \\
X2 & 0.551094 & 0.436721 & 1.261890 & 0.2102 \\
X3 & -0.004488 & 0.005584 & -0.803781 & 0.4236 \\
X4 & 0.243763 & 0.191075 & 1.275745 & 0.2053 \\
X5 & -0.253980 & 0.097019 & -2.617845 & 0.0104 \\
X6 & 0.003091 & 0.001760 & 1.756533 & 0.0824 \\
R-squared & 0.207954 & Mean dependent var & 8.170206 \\
Adjusted & 0.155151 & \multicolumn{3}{c}{ S.D. dependent var } \\
R-squared & \multicolumn{3}{c}{0.941491} \\
\hline
\end{tabular}

Source: Eviews 9.0 (Processed Data)

Table 3.2 shows that the impact of free cash flow $\left(\mathrm{X}_{1}\right)$ is significant toward the dividend payout ratio, as the probability is lower than p-value $(0.05$ or $5 \%)$. The coefficient of free cash flow means every 1 point of change in free cash flow, there will be 2.85 point of change in dividend payout ratio. Free cash flow remains on operating costs and investments needed by agricultural company to maintain and increase cash flow. When a company has a free cash flow, the company is considered to have satisfactory financial flexibility. Managers will get pressure from shareholders to distribute dividends to avoid the possibility of managers making adverse investments (Mahadwartha, 2007).

In addition, the coefficient of leverage $\left(\mathrm{X}_{4}\right)$ is 0.243 and the probability is greater than 0.05 . The result showed that leverage has no significant effect toward the dividend payout ratio, when the leverage increase by 1 point the dividend payout ratio will increase 0.243 . This result supports the research of Puspita (2009) and Thanatawee (2011). The sixth variable, Investment opportunity set $\left(\mathrm{X}_{6}\right)$, has significant effect toward the dividend payout ratio because the probability is lower than $10 \%$ and the coefficient is 0.003 .

In conclusion, investment opportunity set has positive relationship with dividend payout ratio and this result supporting a research from Andasawari et al (2013), Mahadwartha and Hartono (2002). Agricultural Companies that have high investment opportunities will be able to increase dividend payments. Therefore, significant level at $10 \%$ means high investment opportunities guarantee that the level of dividends paid is high. 
Table 3. Fixed Effect Model Result

\begin{tabular}{ccccc}
\hline Variable & Coefficient & Std. Error & t-Statistic & Prob. \\
\hline C & -2.538116 & 7.951842 & -0.319186 & 0.7506 \\
X1 & 0.093449 & 1.327054 & 0.070419 & 0.9441 \\
X2 & 0.209025 & 0.836939 & 0.249749 & 0.8036 \\
X3 & 0.017551 & 0.049363 & 0.355554 & 0.7234 \\
X4 & 1.034539 & 0.549413 & 1.882991 & 0.0643 \\
X5 & -0.066567 & 0.097091 & -0.685610 & 0.4955 \\
X6 & 0.000462 & 0.002556 & 0.180635 & 0.8572 \\
\hline
\end{tabular}

Source: Eviews 9.0 (Processed Data)

Table 3.3 explains that leverage $\left(\mathrm{X}_{4}\right)$ has significant effect toward dividend payout ratio since leverage has lower probability value than $10 \%$ and the rest of other variable have higher probability value than $10 \%$. When the leverage $\left(\mathrm{X}_{4}\right)$ increases by 1 point, the dividend payout ratio will increase 1.034 .

There are several variables effect dividend payout ratio positively although they are not significant; free cash flow $\left(\mathrm{X}_{1}\right)$, life cycle $\left(\mathrm{X}_{2}\right)$, firm size $\left(\mathrm{X}_{3}\right)$ leverage $\left(\mathrm{X}_{4}\right)$, and investment opportunity set $\left(\mathrm{X}_{6}\right)$. Assets growth $\left(\mathrm{X}_{5}\right)$ has weak negative impact toward dividend payout ratio.

Table 4. Random Effect Model Result

\begin{tabular}{ccccc}
\hline Variable & Coefficient & Std. Error & t-Statistic & Prob. \\
\hline C & 7.348058 & 1.772375 & 4.145882 & 0.0001 \\
X1 & 2.130508 & 0.926387 & 2.299804 & 0.0238 \\
X2 & 0.397343 & 0.484263 & 0.820512 & 0.4141 \\
X3 & -0.003677 & 0.006755 & -0.544364 & 0.5875 \\
X4 & 0.248815 & 0.221124 & 1.125228 & 0.2635 \\
X5 & -0.162721 & 0.087140 & -1.867341 & 0.0651 \\
X6 & 0.003092 & 0.001756 & 1.760157 & 0.0818 \\
R-squared & 0.115187 & Mean dependent var & 5.208447 \\
Adjusted R-squared & 0.056200 & S.D. dependent var & 0.767361 \\
\hline
\end{tabular}

Source: Eviews 9.0 (Processed Data)

Table random effect model above shows that free cash flow $\left(\mathrm{X}_{1}\right)$ is positive and has significant level at 5\%. When the free cash flow increases by 1 point, the dividend payout ratio will increase by 2.130 . According to (Mahadwartha, 2007) when a company has a free cash flow, the company is considered to have satisfactory financial flexibility. Managers will get pressure from shareholders to distribute dividends to avoid the possibility of managers making adverse investments.

\section{F-Test (Chow Test) Result}

In order to determine the best model for interpreting the panel results, this research used several tests including this F-test. This test has been used to determine whether Fixed Effect Model is better than Common Effect Model. 
Table 5. F-Test (Chow Test) Result

\begin{tabular}{llll}
\hline \multicolumn{1}{c}{ Effects Test } & \multicolumn{1}{c}{ Statistic } & \multicolumn{1}{c}{ d.f. } & \multicolumn{1}{c}{ Prob. } \\
\hline Cross-section F & 2.757636 & $(27,63)$ & 0.0005 \\
Cross-section Chi-square & 75.676522 & 27 & 0.0000 \\
\hline
\end{tabular}

Source: Eviews 9.0 (Processed Data)

As shown in the table, the result of the cross-section $\mathrm{F}$ probability is lower than p-value $(0.0005<0.05)$. Therefore, we should reject the $\mathrm{H}_{0}$ and accept $\mathrm{H}_{1}$, it means FEM is better to be applied on this research rather than CEM. The Fixed Effect Model method uses an assumption that all intercepts are different from each cross section, while the slopes remain constant.

\section{Hausman Test Result}

Hausman also developed a test to see if FEM is better than REM. This test is based on an idea of whether LSDV is more successful on FEM than on /GLS REM. The null hypothesis will therefore be that GLS is more effective than LSDV, and the opposite is true for alternative hypothesis (Nachrowi\& Usman, 2006).

Table 6. Hausman Test Result

\begin{tabular}{llll}
\hline \multicolumn{4}{c}{ Correlated Random Effects - Hausman Test } \\
\hline Test Summary & Chi-Sq. & Chi-Sq. d.f. & Prob. \\
& Statistic & & \\
Cross-section random & 17.006176 & 6 & 0.0093 \\
\hline
\end{tabular}

Source: Eviews 9.0 (Processed Data)

The result from table 3.6 clearly shows that the value of the cross-section random probability is lower than p-value $(0.0093<0.05)$. Therefore, we should reject null hypothesis, which means fixed effect model is the best method to estimate the data.

Table 7. Multicollinearity Test Result

\begin{tabular}{ccccccc}
\hline & $\mathbf{X 1}$ & $\mathbf{X 2}$ & $\mathbf{X 3}$ & $\mathbf{X 4}$ & $\mathbf{X 5}$ & $\mathbf{X 6}$ \\
\hline $\mathbf{X 1}$ & 1 & 0.179226 & 0.12563 & -0.09795 & -0.05208 & -0.01615 \\
$\mathbf{X 2}$ & 0.17922 & 1 & -0.10270 & -0.24910 & -0.08608 & -0.16528 \\
$\mathbf{X 3}$ & 0.12563 & -0.10270 & 1 & 0.42371 & 0.04430 & 0.05264 \\
$\mathbf{X 4}$ & -0.09795 & -0.24910 & 0.42371 & 1 & 0.18415 & 0.07022 \\
$\mathbf{X 5}$ & -0.05208 & -0.08608 & 0.04430 & 0.18415 & 1 & 0.06782 \\
$\mathbf{X 6}$ & -0.01615 & -0.16528 & 0.05264 & 0.07022 & 0.06782 & 1 \\
\hline
\end{tabular}

Source : Eviews 9.0 (Processed Data)

There will be multi-collinearity if the variables value more than 0.9 (Ghozali, 2013). From the table above, the lowest result is between X2 and X4 which is $-25 \%$ and the highest result is between $\mathrm{X} 3$ and $\mathrm{X} 4$ which is $42 \%$, there is no variable that have coefficient of correlation more than 0.9. Therefore, there is no multi-collinearity in this research.

\section{Heterosdasticity Test}

The assumption of homoscedasticity is central to linear regression models. Homoscedasticity describes a situation in which the error term is the same across all values of 
the independent variables. Heteroscedasticity is present when the size of the error term differs across values of an independent variable. The impact of violating the assumption of homoscedasticity is a matter of degree, increasing as heteroscedasticity increases.

Table 8. Fixed Effect Model Result

\begin{tabular}{ccccc}
\hline Variable & Coefficient & Std. Error & t-Statistic & Prob. \\
\hline C & -2.538116 & 7.951842 & -0.319186 & 0.7506 \\
X1 & 0.093449 & 1.327054 & 0.070419 & 0.9441 \\
X2 & 0.209025 & 0.836939 & 0.249749 & 0.8036 \\
X3 & 0.017551 & 0.049363 & 0.355554 & 0.7234 \\
X4 & 1.034539 & 0.549413 & 1.882991 & 0.0643 \\
X5 & -0.066567 & 0.097091 & -0.685610 & 0.4955 \\
X6 & 0.000462 & 0.002556 & 0.180635 & 0.8572 \\
R-squared & 0.636983 & Mean dependent var & 8.170206 \\
Adjusted R-squared & 0.446831 & S.D. dependent var & 0.941491 \\
Log likelihood & -82.14093 & Hannan-Quinn criter. & 2.759576 \\
F-statistic & 3.349869 & Durbin-Watson stat & 1.547154 \\
Prob(F-statistic) & 0.000018 & & \\
\hline
\end{tabular}

Source: Eviews 9.0 (Processed Data)

\section{CONCLUSION}

The result of this study supports the result of studies from of Gustiana (2009), Rosdini (2009), Holder et al (1998) and Mollah et al (2002). Free cash flow does not significantly influence the dividend payout ratio and is positively related to the dividend payout ratio of agricultural companies that listed in Indonesia Stock Exchange, the greater the free cash flow, the greater the dividend payout ratio and vice versa. Positive free cash flow means that agricultural company is able to use internal funding to fulfill company investment. According to Rosdini (2009) positive free cash flow can also be used as form of cash reserves for dividend distribution.

This study also agrees that the life cycle does not have a significant impact on dividend payout ratio of agricultural companies that listed in Indonesia stock exchange. This result indicated by the magnitude of the probability value that far exceeds $10 \%$. However, in the implementation life cycle has a positive impact on dividend payout ratio proves with the increasing of dividend payout ratio at 0.209 point. This study supports the hypothesis and theory of De Angelo et al (2006), Lestari (2012), Denis and Osobov (2008) stated that life cycle have positive impact with dividend payout ratio. In the future, further research should expand more in time period and particular variable that compatible with the characteristics of agricultural companies in Indonesia.

\section{REFERENCES}

Allen, F., \& Michaely, R. (2003). Payout Policy. Working Paper Series.

Andasawari, S., Pitono, H., Iskandar, R. (2017). Analysis the Effect of Investment Opportunity Set (IOS) on the Dividend Policy of Constructions Companies Listed on the Indonesia Stock Exchange.

Black, F. (1976). The Dividend Puzzle. Journal of Portofolio Management 2, 5-8. 
Brennan, M. J., \& Thakor, A. V. (1990). Shareholder Preferences and Dividend Policy. The Journal of Finance, 993-1018.

DeAngelo, H., DeAngelo, L., \& Stulz, R. M. (2006). Dividend Policy and the Earned/ Contributed Capital Mix: A Test of the Lifecycle Theory. Journal of Financial Economics, 227-254.

Denis, D. J., \& Osobov, I. (2008). Why Do Firms Pay Dividends? International Evidence on the Determinants of Dividend Policy. Journal of Financial Economics, 62-82.

Gustiana, N. (2009). Pengaruh Insider Ownership, Dispersion of Ownership, Free Cash Flow, Collaterizable Assets dan Tingkat Pertumbuhan Terhadap Dividend Payout Ratio Pada Perusahaan- Perusahaan Manufaktur di Bursa Efek Indonesia Tahun 2004- 2008.

Gordon, M. J. (1963). Optimal Investment and Financing Policy. The Journal of Finance, 264-272.

Holder, M., Langrehr, F., \& Hexter, J. (1998). Dividend Policy Determinants: An Investigation of the Influences of Stakeholder Theory. Financial management 27, 7380 .

Kallapur, S., \& Trombley, M. A. (1999). The Association Between Investment Opportunity Set Proxies and Realized Growth. Journal of Business Finance and Accounting, Vol. 26, pp. 505-519.

Keown, A. J., Martin, J. H., Petty, J. W., \& Scott, D. F. (2003). Financial Management : Principles and Applications 10th ed. New Jersey: Prentice Hall.

Lestari, J. S. (2012). Determinants of Dividend Decision: Evidence From the Indonesia Stock Exchange. Integr. Bus. Econ. Res., 1(1) 346.

Levy, H., \& Sarnat, M. (1990). Capital Investment and Financial Decision 4th ed. New York: Prentice Hall.

Lintner, J. (1962). Dividends, Earnings, Leverage, Stock Prices and the Supply of Capital to Corporation. The Review of Economics and Statistics, 243-269.

Mahadwartha, P. A. (2007). The Association of Managerial Ownership with Dividend Policy and Leverage Policy: Indonesian Firm. SSRN Working Papers Series.

Miller, M. H., \& Modigliani, F. (1961). Dividend Policy, Growth and the Valuation of Shares. The Journal of Business, Vol. 34 No. 4, pp. 411-433.

Mollah, A. S., Keasey, K., \& Short, H. (2002). The Influence of Agency Costs on Dividend Policy in An Emerging Market: Evidence from the Dhaka Stock Exchange. Working Paper, Leeds University Business School.

Nachrowi, N. D., \& Usman, H. (2002). Penggunaan Teknik Ekonometri. Jakarta: PT RajaGrafindo Persada.

Puspita, F. (2009). Anallisis Faktor- Faktor yang Mempengaruhi Kebijakan Dividend Payout Ratio (Studi Kasus pada Perusahaan Yang Terdaftar di Bursa Efek Indonesia Periode 2005-2007).

Rosdini, D. (2009). Pengaruh Free Cash Flow terhadap Dividend Payout Ratio. Working paper in Accounting and Finance.

Suharli, M., \& Rachpriliani, A. (2006). Studi Empiris Faktor yang Berpengaruh terhadap Ketepatan Waktu Pelaporan Keuangan. Jurnal Bisnis dan Akuntansi, Vol.8 No.1 (April): 34-55.

hanatawee, Y. (2011). Life-Cycle theory and Free Cash Flow Hypothesis: Evidence from Dividend Policy in Thailand. International Journal of Financial Research 2. 